\title{
First report of Chrysodeixis includens (Walker, [1858]) (Lepidotera: Noctuidae) Injurious to Pineapple (Ananas comosus L.) (Bromeliaceae) in Brazil
}

\author{
A. M. Detoni ${ }^{a}$, S. L. C. Carvalho ${ }^{b}$, A. T. Hoshino, M. A. Pastório ${ }^{c}$, M. A. H. Schmidt , \\ A. O. Menezes Junior ${ }^{c}$ and H. G. Androciolib* \\ anstituto Agronômico do Paraná - IAPAR, Polo de Santa Tereza do Oeste, Rodovia BR 132, Km 188, \\ CEP 85825-000, Santa Tereza do Oeste, PR, Brazil \\ 'Instituto Agronômico do Paraná - IAPAR, Rodovia Celso Garcia Cid, PR 445, Km 375, CEP 86047-902, \\ Londrina, PR, Brazil \\ 'Universidade Estadual de Londrina - UEL, Rodovia Celso Garcia Cid, PR 445, Km 380, Campus Universitário, \\ CP 10.011, CEP 86057-970, Londrina, PR, Brazil \\ *e-mail: humbertoandrocioli@gmail.com
}

Received: January 13, 2017 - Accepted: July 4, 2017 - Distributed: November 30, 2018

(With 1 figure)

The pineapple plant (Ananas comosus L.) (Bromeliaceae) is an important fruit crop of Brazil, which is the second largest pineapple producer in the world, with an estimated annual production of 3.3 million tons in 2014 , generating approximately a million dollars in exports (Reetz et al., 2015). The crop is well adapted to the subtropical climate of the warmer regions of Paraná state. The most significant of the several pests and diseases that attack the pineapple crop in the state are the scale insect Dysmicoccus brevipes (Cockerell, 1893) (Pseudococcidae) and fusariosis caused by Fusarium subglutinans (Wollenweber \& Reinking, 1983) (Nectriaceae), as well as the fruit borer Strymon megarus (Godart, [1824]) (Lycaenidae) and the nematodes Pratylenchus brachyurus (Godfrey, 1929) (Pratylenchidae), and Meloidogyne spp. (Heteroderidae) (Carvalho et al., 2015).

The occurrence of lepidopterans, which causes significant harm and limits pineapple production, is well known. The most important lepidopterans to affect pineapple production are Castnia icarus (Cramer, 1775) (Castniidae), Elaphria agrotina (Guenée, 1852) (Noctuidae), and S. megarus (Gallo et al., 2002), with the last one being able to cause production losses varying from 47 to $80 \%$, depending on the pineapple variety (Faria et al., 2009; Sanches, 2005).

The lepidopteran Chrysodeixis includens (Walker, [1858]) (Noctuidae) is a widely distributed pest in the Americas, occurring from the north of the United States to the south of South America (Moscardi et al., 2012). In Brazil, populations of this lepidopteran are found in the entire soybean producing region, extending from the state of Roraima, in the extreme north of the country, to the state of Rio Grande do Sul, in the extreme south (Marsaro Junior et al., 2010).

Although soybean crops are apparently the preferred hosts for the development of $C$. includens, there are 73 other host plants in Brazil, the majority of them being economic importance (Bernardi, 2012). This demonstrates the polyphagous capacity of the lepidopteran that allows its adaptation to diverse environments. The present study reports the occurrence of $C$. includens for the first time in a pineapple crop.

The presence of $C$. includens caterpillars was observed in pineapple plants (cv. Smooth Cayenne) during March 2015 at the Experimental Station of the Agronomic Institute of Paraná, in the municipality of Santa Helena, Parana state (latitude $24^{\circ} 51^{\prime} 37^{\prime}$ ' S, longitude 5419' $58^{\prime}$ ' W, and elevation 172 m.a.s.1.). The infested plants were 20 months old (in full bloom), growing in an area of approximately 0.6 ha adjacent to a final-stage soybean crop (see Figure 1A). The caterpillars had a light green color with longitudinal white stripes interspersed with black dots along the body (see Figure 1B, C, and D). Specimens of fourth and fifth instar larvae were collected from the plants and sent to the Entomology Laboratory of Agronomic Institute of Paraná, where they were kept under ambient conditions and fed soybean leaves until the emergence of the adults for confirmation of their identity.

The lesions caused by $C$. includens were observed as soon as the fruits were formed. Initially, the caterpillars were observed feeding on the floral remains of the pineapple plant (see Figure 1C and D), causing holes in the fruit (see Figure 1E) and reaching their pulp (see Figure 1F). Up to six caterpillars per fruit were found. Furthermore, damage was also observed on the leaves, which progressed to necrosis (see Figure 1B).

In contrast to other crops, such as soybean, which can tolerate 33\% loss of leaves (Bueno et al., 2010), lesions are not tolerated in pineapple fruits without further processing (sold in natura), due to "aesthetic damage". Overall 95\% of the fruits produced in the crop area presented damages that reached its pulp, making it unviable for the in natura trade. Thys way it is estimated that $95 \%$ of the production is lost, which is greater than the $80 \%$ loss reported for infestation with $S$. megarus, the main lepidopteran pest affecting the crop (Sanches, 2005). Moreover, it was 

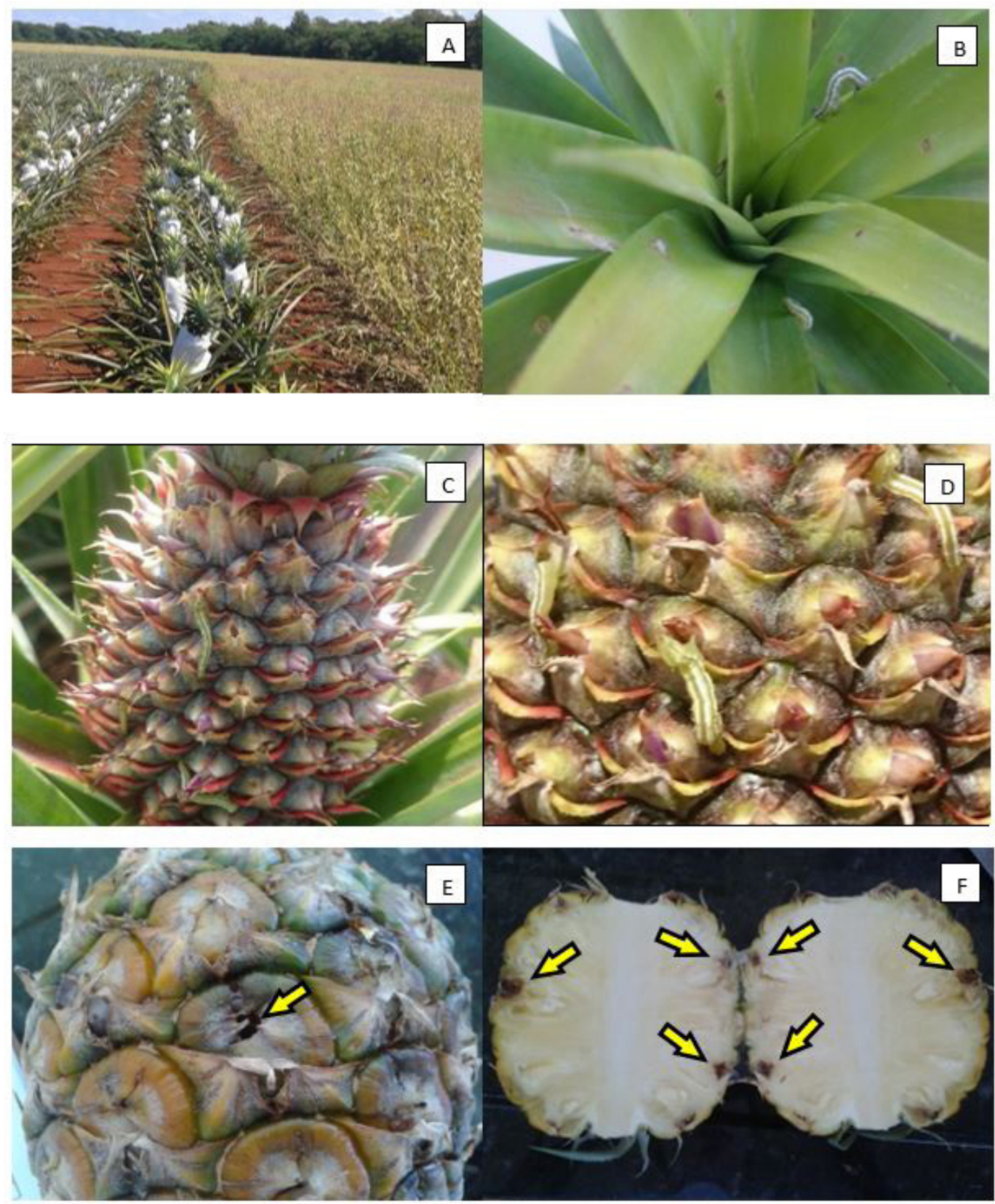

Figure 1. Pineapple plantation near a soybean crop (A). Presence of caterpillars and damage caused to pineapple leaves (B). Caterpillars consuming flower remains (C and D). External (E) and internal damage (F) to the fruit (see arrows). Photos: Alessandra Maria Detoni and Michele Alessandra Hartmann Schmidt.

observed that $C$. includens ate the leaves of all the affected plants, a habit rarely noted in S. megarus (Matos et al., 2007), revealing the potential harm that $C$. includens can cause to a crop.

In the United States, $C$. includens is considered to be migratory (Harding, 1976), with greater populations occurring near cotton and soybean crops (Burleigh, 1972). It is possible that composition of the agricultural landscape (with adjacent soybean crops in their final stage), combined with the polyphagous habit of the pest, might have favored its occurrence in the pineapple crops. Owing to the selection pressure exerted by the environment, a polyphagous pest must be considered a "production system pest" rather than a "crop pest" as reported for other lepidopteran pests (McCaffery, 1998; Ventura et al., 2015).

The changes related to the landscape composition and increase in the population density of insects are factors that might explain not only the attack of $C$. includens on pineapple plants in the western region of the Parana state, but also of many other insect pests on different agricultural 
crops. Several recent studies have reported the occurrence of new pests on agricultural crops in Brazil. These include incidences of Heliothis virescens (Fabricius, 1781) (Lepidopetra: Noctuidae) causing damage in vineyards (Ventura et al., 2015), Cyclocephala flavipennis Arrow, 1914 (Coleoptera: Melolonthidae) occurring on blueberries (Díez-Rodriguez et al., 2015), Euphoria lurida (Fabricius, 1775) (Coleoptera: Scarabaeidae) attacking safflower (Androcioli et al., 2017), and Naupactus cinerosus (Boheman, 1833) (Coleoptera: Curculionidae) causing damage to cassava plants (Barbosa et al., 2012).

Considering the conditions observed in the agrosystem involving pineapple cultivation, it is recommended that pineapple crops planted adjacent to soybean plantations are monitored periodically to identify and prevent possible infestations that may lead to significant production losses.

\section{References}

ANDROCIOLI, H.G., HOSHINO, A.T., PASTÓRIO, M.A., CARDOSO, P.C., ARAÚJO, P.M., FERNANDES, T.A.P. and MENEZES JUNIOR, A.O., 2017. First Record of Euphoria lurida Fabricius (Coleoptera: Scarabaeidae) Injurious to Safflower (Carthamus tinctorius L.) (Asterales: Asteraceae) in Brazil. Neotropical Entomology, vol. 46, no. 1, pp. 130-132. http://dx.doi. org/10.1007/s13744-016-0434-6. PMid:27553719.

BARBOSA, R.H., KASSAB, S.O., PEREIRA, F.F., RAMOS, R.V. and SILVA, A.S., 2012. Primeiro relato de Naupactus cinerosus Boheman, 1833 (Coleoptera: Curculionidae) para a cultura de mandioca no Brasil. Entomotropica, vol. 27, no. 1, pp. 41-44.

BERNARDI, O. 2012. Avaliação do risco de resistência de lepidópteros-praga (Lepidoptera: Noctuidae) à proteína CrylAc expressa em soja MON 87701 x MON 89788 no Brasil. Piracicaba: Escola Superior de Agricultura "Luiz de Queiroz", Universidade de São Paulo, 144 p. Tese de Doutorado em Entomologia.

BUENO, A.F., BATISTELA, M.J., MOSCARDI, F., BUENO, R.C.O.F., NISHIKAWA, M., HIDALGO, G., SILVA, L., GARCIA, A., CORBO, E. and SILVA, R.B. 2010. Niveis de desfolha tolerados na cultura da soja sem a ocorrência de prejuízos a produtividade. Londrina: Embrapa Soja, 11 p.

BURLEIGH, J.G., 1972. Population dynamics and biotic controls of the soybean looper in Louisiana. Environmental Entomology, vol. 1, no. 3, pp. 290-294. http://dx.doi.org/10.1093/ee/1.3.290.

CARVAlHO, S.L.C., AUlER, P.A.M. and DETONI, A.M. 2015. Abacaxi: cultivo nas condições subtropicais do Paraná. Londrina: IAPAR, $4 \mathrm{p}$.

DIEZ-RODRÍGUEZ, G.I., HÜBNER, L.K., ANTUNES, L.E.C., GUEDES, J.V.C. and NAVA, D.E., 2015. Registro de Cyclocephala flavipennis Arrow, 1914 (Coleoptera: Melolonthidae) danificando plantas de mirtileiro no Brasil. Ciência Rural, vol. 45, no. 2, pp. 189-191. http://dx.doi.org/10.1590/0103-8478cr20140412.

FARIA, D.C., CARVALHO, A.J.C., COELHO, R.I. and OLIVEIRA JÚNIOR, J.C., 2009. Bud moth (Strymon megarus (Godart, 1824)) causes severe losses in young plants of pineapple cultivars Pérola and Smooth Cayenne in Rio de Janeiro, Brazil. Acta Horticulturae, no. 822, pp. 219-224. http://dx.doi.org/10.17660/ ActaHortic.2009.822.27.

GALLO, D., NAKANO, O., SILVEIRA NETO, S., CARVALHO, R.P.L., BAPTISTA, G.C., BERTI FILHO, E., PARRA, J.R.P., ZUCCHI, R.A., ALVES, S.B., VENDRAMIM, J.D., MARCHINI, L.C., LOPES, J.R.S. and OMOTO, C. 2002. Entomologia agrícola. Piracicaba: Editora FEALQ, $920 \mathrm{p}$

HARDING, J.A., 1976. Seasonal occurrence, hosts, parasitism and parasites of cabbage and soybean loopers in the lower Rio Grande Valley. Environmental Entomology, vol. 5, no. 4, pp. 672-674. http://dx.doi.org/10.1093/ee/5.4.672.

MARSARO JUNIOR, A.L., PEREIRA, P.R.V.S., SILVA, W.R. and GRIFFEL, S.C.P., 2010 [viewed 13 January 2017]. Flutuação populacional de insetos-praga na cultura da soja no estado de Roraima. Revista Acadêmica de Ciências Agrárias e Ambientais, vol. 8, no. 1, pp. 71-76. Available from: http://www. alice.cnptia.embrapa.br/handle/doc/886360

MATOS, A.P., SANCHES, N.F., SOUZA, L.F.S., TEIXEIRA, F.A. and ELIAS JÚNIOR, J. 2007. Manual de identificação de pragas, doenças e deficiências nutricionais da cultura do abacaxi. Cruz das Almas: Embrapa Mandioca e Fruticultura Tropical, 42 p.

MCCAFFERY, A.R., 1998. Resistance to insecticides in heliothine Lepidoptera: a global view. Philosophical Transactions of the Royal Society of London. Series B, Biological Sciences, vol. 353, no. 1376, pp. 1735-1750. http://dx.doi.org/10.1098/rstb.1998.0326.

MOSCARDI, F., BUENO, A.F., SOSA-GÓMEZ, D.R., ROGGIA, S., HOFFMAN-CAMPO, C.B., POMARI, A.F., CORSO, I.C. and YANO, S.A.C. 2012. Atrópodes que atacam as folhas de soja. In: C.B. HOFFMAN-CAMPO, B.S. CORRÊA-FERREIRA and F. MOSCARDI, eds. Soja: manejo integrado de insetos e outros artrópodes-praga. Brasília: Embrapa, pp. 213-334.

REETZ, E.R., KIST, B.B., SANTOS, C.E.S., CARVALO, C. and DRUM, M. 2015. Anuário brasileiro da fruticultura 2015. Santa Cruz do Sul: Gazeta Santa Cruz, 104 p.

SANCHES, N.F. 2005 Manejo integrado da broca-do-fruto do abacaxi. Cruz das Almas: Embrapa Mandioca e Fruticultura Tropical, 2 p. Abacaxi em Foco, no. 36.

VENTURA, M.U., ROBERTO, S.R., HOSHINO, A.T., CARVALHO, M.G., HATA, F.T. and GENTA, W., 2015. First record of Heliothis virescens (Lepidoptera: Noctuidae) damaging table grape bunches. The Florida Entomologist, vol. 98, no. 2, pp. 783-786. http://dx.doi.org/10.1653/024.098.0259. 